\title{
Claudiu T. Arieșan, Istoria comicului românesc, Editura Datagroup, Timişoara, 2016, 580 p.
}

\author{
Laura Bădescu* \\ "G. Călinescu” Institute of Literary History and Theory, Calea 13 Septembrie 13, 050711 Bucharest, Romania
}

The monographic route of Istoria comicului românesc [The History of Romanian Comic] (2016) by Claudiu T. Arieșan was announced by two previous volumes: Hermeneutica umorului simpatetic. Repere pentru o comicologie românească [The Hermeneutics of sympathetic humour. Highlights for a Romanian comicology] (1999) and Între surâs și rugăciune. Modele culturale din comicologia clasică și patristică [Between smile and prayer. Cultural models of the classical and patristic comicology] (2003).

The hermeneutic route of this paper has, in order to cover such a vast subject, multiple starting points. Thus, as a reference system we have the great Hellenic philosophical and æsthetic theories (Plato, Xenophon, Democritus, Heraclitus, Aristotle) and the rhetoric ones practiced or theorized by the orators of Rome (Cicero, Democritus, Quintilian, Pliny the Younger). With a major foray in the Renaissance, but also in the major currents of culture: classicism, Enlightenment, Romanticism, without ignoring the directions imposed by Hegel, Schopenhauer, Vischer, Nietzsche, Hartmann, Croce etc., the critical approach sets a cultural map punctuated with definitions, classifications, options, interpretations, rankings. In an integrating effort of which the conductor wire is not missing, the author clarifies confusion, specifies concepts, operates with distinctions that he captures in diachronic evolution, seeks in an exhaustive cultural area, the semantic changes of the terms and, especially, establishes conclusions. Among the entries in the sympathetic history placed under the anthropological perspective, the interesting ones remain those which deny the interesting cultural prejudices. Talking about the sacred essence and the religious dimension of laughter, the author pursues their assertion both in the Old and the New Testament, as well as in the works of scholars such as Ephrem the Syrian, Ioan Scărarul, Tomas Aquinas, etc.

*Email address: laura.e.badescu@gmail.ro. the relationship to ethnic also appears as interesting. This is a natural step since "distinct historical developments, psychological matrices contributed in time to the crystallization of differences among peoples, nations, races and ethnic groups on the manner of conceiving, issuing and receiving humorous ways". The typologies proposed in this key remind us of the medieval Arithmology and suggest the assimilation into a new context of the old medieval projection tools. Imagologically, these types reconfirm that "nothing of the paideic can be lost, but everything transforms before our eyes, in the field of the ancient and medieval humanities".

The approach from this angle of the space of old Romanian literature is achieved from the old author's text (predosloviile - foreword, introduction) towards the serious text (historiography) and to the delay ones (rhymed chronicles), reaching the first accepted encyclopædist: Prince Cantemir. Between these borders the excursus is new for our ancient texts have rarely been interpreted in the key of this study.

This gap can be attributed to two major constraints. On the one hand, constraints existing in our cultural history, set and propagated through customs and mentalities. Undoubtedly, the individuals of old ages, chroniclers and historians, translators and writers of religious texts could not ignore the integrated status of those who made jokes. The need for status of the individual who writes for eternity (the letter is an eternal thing - said the chronicler) and his real seriousness (or faked) were the essential coordinates of his public figure. Writing in the joking was not allowed or rather he could not afford to do this. The old author was a seeker of knowledge and a sower of wisdom. Therefore, the call to paremiology, for example, is the first fabulous mask under which people laugh in our old and pre-modern literature. (I add in parenthesis that most of the popular books 
translated in the era, rarely bore the name of the author or translator; the delay literature tasted at the time placed into anonymity the things băznuite (shaped) from a shame that the Romanians have had in abundance. Even our early poem, written in the shade of the cup full of illustrious men like Conachi or Ioan Cantacuzino, was not signed...)

Among those who could make jokes, there were the itinerant actors-called quackery or playfulwhose social status was ungrateful, as it can be seen in our legal system. Thus, Pravila [Rule] of Iași (1814) stated: "and again after the rule, bailiff or advocate cannot be received at trial without choice as well as the deaf and the minor, the one who has not turned 17 and the who was guilty of death, and the one who has been proven to be a false accuser, and the playful and other dishonest people like that".

The second major constraint comes from the scarcity of studies that place the comprehension of the old text under the sign of laughter. Only the return to the era, to the author and his status, to the circumstances that allow and condition the appearance of text and its reception could draw the real patterns of this category. Otherwise, the laughter of the old cannot be discerned in contemporary patterns.

The fact that Professor Claudiu Arieșan tries to restore this climate from the inside is a win for the sizing of the Romanian comic in the ancient text. So, as forerunners say, stretched ahead is the smooth and bright path of unravelling the meaning - and the hermeneutic effort saves both the old author and the new receiver. 